\title{
ME-REVIEW PEMIKIRAN PARA FILSUF ATAS KONSEPSI MASYARAKAT DALAM BUKU "REALITAS SOSIAL, REFLEKSI FILSAFAT SOSIAL ATAS HUBUNGAN INDIVIDU-MASYARAKAT DALAM CAKRAWALA SEJARAH SOSIOLOGI"
}

\author{
I Ketut Wisarja ${ }^{1}$, Ni Nyoman Suastini ${ }^{2}$ \\ Universitas Hindu Negeri I Gusti Bagus Sugriwa Denpasar ${ }^{1,2}$ \\ wisarjaiketut@gmail.com ${ }^{1}$,nyomansuastini4@gmail.com²
}

\begin{abstract}
Society is a unity of human life that can be mutually exclusive according to certain rules, norms, and customs that are continuous and bound by a common identity. It is inevitable that society is formed without individual interaction as the main constituent of society. Therefore, the individual is the key to the idealized form of community building. This article examines the thoughts of several philosophers working in the field of social philosophy and compares them to a complete understanding of the concept of the society they aspire to, namely a social construction that is peaceful, without fear, and far from violent behavior.
\end{abstract}

Keywords: Review, Philosopher's Thought, Community Conception.

\section{PENDAHULUAN}

Pandangan yang berbeda tentang konsep masyarakat seringkali dikemukakan oleh para filsuf, baik filsuf klasik maupun filsuf kontemporer. Perbedaan pandangan tersebut biasanya terjadi karena asumsi dasar yang mengkonstruksi pemikiran para filsuf juga berbeda. Itulah sebabnya, konsepsi masyarakat menjadi banyak variannya tergantung dari sudut pendekatan yang digunakan. Pada judul di atas diketengahkan 'me-review' pemikiran para filsuf, yang dimaksud adalah untuk membandingkan pandangan para filsup tentang konsep masyarakat dan kemudian dapat memahaminya sebagai wujud realisasi diri dari sifat kodrat manusia, yaitu; sebagai mahluk individu dan sekaligus sebagai mahluk sosial.

Sebagai mahluk individu, manusia memang memiliki otonomi sendiri tanpa intervensi dari orang lain, akan tetapi sebagai mahluk sosial, manusia jelas tidak bisa hidup sendiri tanpa orang lain. Hal ini karena sejak dilahirkan manusia sudah mempunyai dua hasrat atau keinginan pokok, yaitu; (a) keinginan untuk menjadi satu dengan manusia lain di sekelilingnya (yaitu masyarakat), (b) keinginan untuk menjadi satu dengan suasana alam sekelilingnya (Soekanto, 1999: 124).

Sedangkan 'masyarakat' dalam bahasa Inggris disebut society, asal katanya socius yang berarti kawan. Adapun kata 'masyarakat' yang berasal dari bahasa Arab, yaitu dari kata 'syirk', artinya bergaul. Adanya saling bergaul ini tentu karena adanya bentuk-bentuk aturan hidup, yang bukan disebabkan oleh manusia sebagai perseorangan, melainkan oleh unsurunsur kekuatan lain dalam lingkungan sosial yang merupakan kesatuan (Soelaiman, 1993:63). Para ahli sepakat bahwa adanya saling bergaul dan interaksi karena mempunyai nilai-nilai, norma-norma, cara-cara dan prosedur yang merupakan kebutuhan bersama sehingga masyarakat merupakan kesatuan hidup manusia yang berinteraksi menurut suatu 
sistem adat-istiadat tertentu yang bersifat kontinyu dan terikat oleh suatu rasa identitas bersama.

Pengertian masyarakat yang demikian menunjukkan kecenderungan kuat bahwa masyarakat terbentuk oleh hubungan interaksional antara berbagai individu yang mempunyai ikatan-ikatan bersama yang menjadi identitas. Kesamaan identitas awalnya menjadi sarana bagi terbentuknya ikatan-ikatan antara individu, lambat laun masyarakat tidak lagi terbentuk hanya dengan kesamaan identitas, melainkan juga oleh kesamaan kepentingan dan tujuan bersama. Dengan demikan titik tolak terbentuknya masyarakat diawali oleh terjadinya proses inter-relasi antara individu dalam komunitas untuk bersamasama mencapai tujuan yang disepakati bersama.

Manusia dalam menghadapi dan menyesuaikan diri dengan kedua lingkungan tersebut menggunakan pikiran, perasaan dan kehendaknya. Aktivitas manusia dalam menghadapi dan menyesuaikan diri tersebut pada akhirnya menimbulkan kelompokkelompok sosial (social group) di dalam kehidupannya. Kelompok-kelompok sosial tersebut merupakan himpunan atau kesatuan-kesatuan manusia yang hidup bersama. Hubungan tersebut antara lain menyangkut kaitan timbal balik yang saling pengaruh mempengaruhi dan juga suatu kesadaran untuk saling tolong menolong (Iver, Mac, dan Charles H. Page, 1961: 213). Himpunan manusia dapat disebut sebagai kelompok-kelompok sosial apabila memenuhi berbagai persyaratan, antara lain;

1. Setiap anggota kelompok harus sadar bahwa dia merupakan sebagian dari kelompok yang bersangkutan;

2. Ada hubungan timbal balik antara anggota yang satu dengan anggota yang lainnya;

3. Ada suatu faktor yang dimiliki bersama, sehingga hubungan antara mereka bertambah erat. Faktor tadi dapat merupakan nasib yang sama, kepentingan yang sama, tujuan yang sama, ideologi yang sama, dan lain-lain. Tentunya juga faktor mempunyai musuh bersama misalnya, dapat pula menjadi faktor pengikat atau pemersatu;

4. Berstruktur, berkaidah dan mempunyai pola perilaku;

5. Bersistem dan berproses (Soekanto, 1999: 126).

Pengertian tersebut pada dasarnya hendak menekankan bahwa masyarakat merupakan suatu sistem yang dibangun oleh kelompok atau komponen-komponen yang bekerja secara teratur sebagai suatu kesatuan. Sistem kemasyarakatan terbentuk karena adanya saling hubungan diantara komponen-komponen yang terdapat dalam masyarakat yang bersangkutan sehingga membentuk suatu kesatuan atau suatu integrasi. Integrasi tersebut terjadi berdasar pada kesepakatan dari para anggotanya terhadap nilai-nilai tertentu, atau didasarkan pada general-agreements yang memiliki kekuatan untuk mengatasi perbedaan-perbedaan pendapat dan kepentingan diantara para anggota masyarakat yang bersangkutan.

Secara fungsional masyarakat selalu memperlihatkan sebagai suatu sistem yang terintegrasikan ke dalam bentuk equilibrium. Pandangan ini kemudian mengemuka dengan sebutan integration approach, order approach, atau equilibrium approach; dan lebih terkenal lagi dengan sebutan structural-functional (fungsionalisme struktural) (Mutakim, 1998: 1-2).

Selanjutnya Mutakim (1998: 2) menguraikan pendekatan-pendekatan tersebut menganalogikan atau memandang sama antara masyarakat dengan organisme biologis. Plato misalnya, pernah membagi masyarakat ke dalam tiga kelas, yaitu; penguasa, militer, dan kaum pekerja. Ketiganya memperlihatkan cara berpikir, berasa, besemangat, nafsu sendirisendiri. Pendekatan tersebut kemudian disempurnakan oleh August Comte dengan filsafat positifnya, yang menjelaskan hubungan antara konsep struktur dengan fungsinya yang kemudian dipelopori oleh Herbert Spencer, Emile Durkheim, dan sebagainya. Puncaknya 
dicapai oleh ahli sosiologi Amerika, Talcott Parson yang mempopulerkan pendekatan fungsionalisme-struktural dengan beberapa anggapan dasar sebagai berikut;

1. Masyarakat sebagai sistem daripada bagian yang saling berhubungan;

2. Hubungan antara bagian-bagian itu bersifat ganda dan timbal balik;

3. Integrasi sosial tidak akan pernah tercapai dengan sempurna, namun secara fundamental sistem sosial selalu cenderung ke arah equilibrium yang dinamis, artinya selalu merespon perubahan-perubahan yang dibawa dari luar dan kecenderungan untuk mengendalikan perubahan-perubahan tersebut agar akibat-akibat yang ditimbulkannya minimal;

4. Disfungsi, ketegangan dan distorsi selalu bisa terjadi namun dalam proses dan jangka waktu yang relatif lama akan teratasi melalui penyesuaian-penyesuaian dalam proses pelembagaan (institusionalisasi); integrasi sosial memang tidak akan pernah sempurna, tetapi suatu sistem sosial berproses ke arah itu;

5. Perubahan-perubahan di dalam sistem sosial lumrahnya terjadi di dalam gradual, lewat penyesuaian-penyesuaian dan tidak secara drastis. Perubahan secara revolusioner hanya menghasilkan kulit luarnya saja, sedangkan unsur-unsur sosial budaya sebagai fondasi tidak mengalami perubahan yang berarti;

6. Kekuatan penting yang mengintegrasikan suatu sistem sosial adalah konsensus di antara anggota masyarakat mengenai nilai-nilai tertentu; yang dianggap diterima sebagai kebenaran (mutlak), sehingga nilai ini tidak hanya sebagai sumber penguat integrasi, tetapi juga sebagai unsur yang menstabilkan sistem sosial-budaya itu sendiri (Veeeger, 1993)

Masyarakat dalam konteks ini merupakan bagian dari sistem sosial atau kesatuan hidup manusia. Sebagai sistem sosial, maka masyarakat seringkali diartikan sebagai orangorang yang hidup bersama yang menghasilkan kebudayaan. Koentjaraningrat (1994: 123) mengatakan bahwa masyarakat adalah kesatuan yang bersifat kontinyu dan terikat oleh suatu rasa identitas yang sama. Hal ini menunjukkan bahwa masyarakat sesungguhnya memiliki ciri-ciri; (a) manusia yang hidup bersama, dua atau lebih orang; (b) bergaul dalam jangka waktu relatif lama; (c) setiap anggotanya menyadari sebagai satu kesatuan; (d) bersama membangun sebuah kebudayaan yang membuat keteraturan dalam kehidupan bersama.

Dalam masyarakat terdapat suatu bentuk pranata sosial atau sering disebut sebagai lembaga kemasyarakatan yang merupakan sistem tata kelakuan (norma-norma, nilai-nilai) yang berhubungan dan berkonsentrasi pada aktivitas-aktivitas yang bertujuan untuk memenuhi kompleks-kompleks kebutuhan dalam kehidupan suatu masyarakat. Pranata sosial tersebut berfungsi; (a) sebagai pedoman bersikap dan berperilaku dalam menghadapi masalah-masalah dalam masyarakat yang bersangkutan; (b) menjaga keutuhan masyarakat ; (c) sebagai sistem pengawasan, pengendalian sosial terhadap perilaku para anggotanya.

Terganggunya pranata sosial tersebut seringkali membuat terjadinya kekacauan atau terganggunya harmonissi sosial. Berbagai konflik dan kekerasan yang seringkali melanda masyarakat merupakan representasi dari tidak dipenuhinya pranata sosial yang menjadi pedoman bersama. Hal ini dapat dimengerti karena dalam konstruksi sosial masyarakat, seringkali terjadi perbedaan kepentingan, sehingga perbedaan tersebut kalau tidak dikelola secara baik dapat melahirkan konflik sosial.

Pada dasarnya dalam masyarakat terdapat komponen-komponen yang membangun pranata sosial, yaitu norma-norma masyarakat dan sistem pengendalian. Mutakim (1998: 1011) menguraikan norma-norma tersebut misalnya; (1) cara-cara (usage); sejumlah perbuatan masing-masing individu dalam kelompok masyarakat, seperti cara makan, berpakaian, dan lain-lain; (2) kebiasaan; seperti cara menghormati orang lain, santun bertamu, dan sejenisnya; (3) tata kelakuan; perbuatan-perbuatan yang jelas dilarang dan yang diperbolehkan; seperti suatu ketentuan adat yang ketat, melakukan berbagai bentuk 
kejahatan; (4) adat-istiadat. Disamping terdapat sistem pengendalian atau kontrol dalam pranata sosial. Sistem tersebut seringkali dijalankan melalui; (a) preventif, refresif, (b) persuasif, tanpa kekerasan, (c) koersif, dengan kekerasan, (d) compulsion, menciptakan suatu situasi, (e) pervasion, norma dan nilai yang terus menerus diperkenalkan, (f) pemidanaan atau penghukuman, (g) konpensasi atau konsiliasi, dan (h) remedial, konsiliasi dan terapi, yakni mengembalikan situasi pada keadaan semula.

Hubungan antar norma dalam masyarakat dapat berjalan baik, apabila terjadi melalui proses integrasi secara harmonis. Hubungan tersebut menimbulkan situasi hubungan serta kehidupan sosial yang penuh dengan kesesuaian dan ketaraturan. Namun, hubungan tersebut dapat juga berakhir dengan konflik, apabila prosesnya diawali dengan disintegrasi, sehingga menimbulkan situasi hubungan dan kehidupan sosial menjadi rawan akan berbagai konflik. Kasus-kasus kekerasan dan konflik yang terjadi dalam masyarakat adalah representasi dari ketidak-harmonisan hubungan antar norma tersebut.

Dalam konteks ini menjadi wajar apabila dalam konstruksi masyarakat yang modern sekalipun tidak akan pernah bisa terlepas dari munculnya konflik dan kekerasan yang menimbulkan banyak korban. Situasi-situasi chaos dalam masyarakat yang demikian menghadirkan sejumlah kegetiran yang cukup mengusik naluri kemanusiaan. Itulah sebabnya, banyak orang berusaha melontarkan berbagai pemikiran sekaligus melakukan gerakan sosial untuk melakukan perlawanan terhadap situasi kemasyarakatan yang jauh dari nilai-nilai kemanusiaan.

\section{METODE}

Penelitian ini merupakan penelitian kepustakaan (library research). Objek materialnya adalah konsepsi masyarakat menurut para filsuf, sedangkan objek formalnya adalah filsafat sosial. Sebagai studi kepustakaan, penelitian ini menggunakan metode deskripsi kulitatif untuk menjelaskan konsepsi masyarakat secara apa adanya, kemudian dianalisis dengan menggunakan metode interpretasi dan hermeneutika dari Paul Ricoeur. Melalui metode ini, maka penafsiran atas konsep masyarakat dari para filsuf dapat dijelaskan secara lebih mendalam.

\section{PEMBAHASAN}

\section{Konsepsi Masyarakat Menurut Para Filsuf:}

1.1. Konsepsi Masyarakat Menurut Jean Jacques Rousseau (1712-1778)

Rousseau beranggapan bahwa masyarakat sebagai 'kontrak sosial' yang diadakan antara pihak-pihak otonum. Pemahaman ini menggambarkan suatu persepsi bahwa tidak ada kaitan sosial batiniah yang dari dalam diri manusia mempersatukan mereka menjadi masyarakat. Tidak ada sosialitas berdasar relasi-relasi batiniah yang menjadikan individu mahluk sosial.

Terbentuknya masyarakat adalah sebagai akibat dari adanya perjanjian kerjasama antara dua atau lebih orang yang secara sosial mengikat janji untuk hidup berdampingan. Perjanjian tersebut merupakan konsensus bersama, sehingga masyarakat tidak dapat hidup tanpa adanya kontrak sosial. Individu bukanlah 'sel', sebab istilah ini mengandaikan adanya suatu antar hubungan dari dalam atau suatu posisi fungsional di dalam keseluruhan. Individu adalah 'atom' atau 'molekul' yang sudah lengkap dalam dirinya, berkemauan sendiri dan mampu menggabungkan diri sesukanya dengan atom-atom lain. Mereka bersatu dengan orang lain menurut struktur-struktur lahiriah.

Paradigma yang dikembangkan oleh Rousseau dalam konteks ini adalah bahwa masyarakat merupakan kumpulan-kumpulan individu yang bersama mengikatkan diri dalam kontrak sosial. Masyarakat tidak akan terbentuk tanpa keterlibatan individu sebagai penyusun utama dari masyarakat. Artinya, masyarakat tidak memiliki makna apapun ketika individu di 
dalamnya tidak membentuk satu kesatuan berdasarkan kontrak sosial yang disepakati. Masyarakat bagi Rousseau merupakan struktur. Dalam artian, masyarakat adalah berkumpulnya komponen 'atom-atom' yang disebut individu. Perpisahan komponen tersebut akan berakibat pada rusaknya kontrak sosial.

\subsection{Konsepsi Masyarakat Menurut August Comte (1798-1857)}

Comte merupakan penganut paham positivisme, bahkan ia adalah tokoh yang mengembangkan paham tersebut. Positivisme adalah paham filsafat yang cenderung untuk membatasi pengetahuan benar manusia kepada hal-hal yang dapat diperoleh dengan memakai metode ilmu pengetahuan. Hal positif adalah hal yang mesti dibenarkan oleh setiap orang yang mempunyai kesempatan sama untuk menilainya. Artinya, hanya fakta atau hal yang dapat ditinjau dan diuji, melandasi pengetahuan sah, maka metafisika dan teologi dianggap tidak mempunyai kriteria untuk disebut sebagai pengetahuan.

Pemahaman ini melandasi pengertian Comte tentang masyarakat. Menurutnya, masyarakat pada dasarnya harus dilihat sebagai suatu orde, yaitu suatu susunan yang tetap dan tertib. Orde itu dilatar-belakangi oleh suatu kenyataan, bahwa orang saling membutuhkan dan saling melengkapi sesuai dengan kemampuan mereka masing-masing. Tiap-tiap orang dan tiap-tiap golongan mempunyai tugas kewajibannya sendiri. Masyarakat dengan demikian disusun berdasarkan prinsip pembagian tugas. Jadi 'orde' adalah keadaan normal, yang bertumpu pada sifat sosial manusia, yang disebut zoon politicon (Veeger, 1993: 19).

Susunan masyarakat yang tertib tersebut tidak harus dimaknai sebagai sesuatu yang tidak pernah terjadi perubahan dan perkembangan. Masyarakat bagi Comte bersifat dinamis juga. Oleh karena itulah kehidupan manusia berada di bawah hukum evolusi. Orde senantiasa didampingi kemajuan. Orde dan kemajuan bersaudara kembar, sebab merupakan dua segi dari realitas sosial. Itulah sebabnya Comte mengkonstatir tahap perkembangan masyarakat ke dalam tiga perkembangan, yakni; tahap agama, dimana pada awal perkembangan akal-budi manusia memakai gagasan-gagasan keagamaan untuk menerangkan semua gejala dan kejadian; tahap metafisik, dimana; semua gejala dan kejadian tidak lagi dilihat sebagai langsung disebabkan roh, dewa, atau Yang Mahakuasa, melainkan akal-budi mencari pengertian dan penerangan dengan membuat abstraksiabstraksi dan konsep-konsep metafisik, dan akhirnya menuju pada tahap positivistik, yaitu; pada tahap gejala alam sudah sepenuhnya dapat diterangkan oleh akal-budi berdasarkan hukum-hukumnya yang dapat ditinjau, diuji, dan dibuktikan atas cara empiris. Penerangan ini kemudian menghasilkan pengetahuan yang instrumental.

\subsection{Konsepsi Masyarakat Menurut Herbert Spencer (1820-1903)}

Spencer cenderung memberikan penyamaan persepsi antara masyarakat dengan organisme. Ciri-ciri yang dikenakan pada badan hidup, dapat dikenakan juga pada badan masyarakat. Organisme yang dikemukakan Spencer lebih bersifat positivistis dan deterministis. Baginya, masyarakat adalah organisme. Semua gejala sosial diterangkan berdasarkan suatu penentuan oleh hukum alam. Hukum yang memerintah atas proses pertumbuhan fisik badan manusia, memerintah juga atas proses evolusi sosial.

Menurut Spencer, masyarakat adalah organisme yang berdiri sendiri dan berevolusi sendiri lepas dari tanggung jawab anggotanya dan di bawah kuasa suatu hukum. Spencer memberikan contoh, bahwa fungsi penyelarasan (condination) dan pemersatuan yang di dalam badan manusia dilakukan oleh urat, sedangkan di dalam badan sosial dilaksanakan oleh sistem pemerintahan. Sama seperti tiap-tiap organisme menghasilkan bahan kebutuhannya demi pemeliharaan dan ketahanan badannya, demikian juga masyarakat mempunyai ekonomi demi kelangsungan dan perkembangannya (Veeger, 1993: 39).

Paradigma yang dikembangkan Spencer lebih mementingkan kuasa individu dalam membentuk masyarakat. Individu adalah tidak hanya sekedar anggota dalam masyarakat, 
melainkan individu adalah penyusun dari masyarakat. Tanpa individu maka masyarakat tidak terbentuk ke dalam struktur-strukturnya.

\subsection{Konsepsi Masyarakat Menurut Emile Durkheim (1857-1919)}

Durkheim membagi masyarakat ke dalam dua jenis. Jenis masyarakat kuno dan masyarakat modern. Masyarakat kuno dicirikan oleh suatu solidaritas mekanis. Kata mekanis tidak dipakai dalam arti individualistis atau atomistis. Sebaliknya, kesadaran sebagai individu di zaman purba masih lemah, sedangkan kesadaran kolektif memerintah atas bagian terbesar kehidupan orang. Kepercayaan yang sama, perasaan yang sama, dan tingkah laku yang sama mempersatukan orang menjadi masyarakat. Kesatuan sosial ini disebut 'mekanis', karena anggotanya secara spontan cenderung kepada suatu pola hidup bersama yang sama. Perbedaan antara individu dianggap tidak penting, sehingga tiap-tiap orang selalu dapat diganti oleh orang lain. Perasaan bersatu antara mereka cukup kuat, sebab mereka mempunyai kesadaran kolektif yang satu dengan lainnya sama, yang biasa disebut alam.

Jenis masyarakat yang kedua adalah masyarakat modern. Bagi Durkheim, masyarakat modern disatukan oleh suatu solidaritas organis. Dalam masyarakat jenis ini, terdapat perbedaan antara anggota individual yang membuat mereka bermasyarakat. Setiap individu saling membutuhkan dan oleh karenanya menjadi bergantung satu kepada yang lainnya. Durkheim (dalam Veeger, 1993: 147) menyebutnya 'organis' di bawah pengaruh organisisme. Sebagaimana organ-organ yang berlainan fungsinya menyokong dan menjamin seluruh kehidupan badan, demikian juga pandangan, perasaan, dan tindakan sosial yang berlainan menyangga masyarakat. Dalam masyarakat modern kebebasan individu dan toleransi terhadap keyakinan individual dan caranya masing-masing anggota mengatur hidupnya sendiri sangat menonjol. Bidang-bidang kehidupan yang dikuasai oleh kesadaran kolektif makin menyempit. Masyarakat diandaikan tidak berhak untuk mencampuri urusanurusan peribadi yang makin meluas.

Dalam masyarakat pluralistis, kuatnya pengaruh kesadaran kolektif atas individu berkurang. Kalau semua individu menjadi sama dan diikat oleh solidaritas mekanis, tiap-tiap sikap atau tindakan yang menyimpang dari pola umum akan menimbulkan reaksi negatif masyarakat (Veeger, 1993: 147).

Dari dua tipe masyarakat yang diketengahkan oleh Durkheim, yakni masyarakat kuno dan masyarakat modern seolah-olah membenturkan pandangan 'organisisme' versus 'mekanisisme'. Dalam pandangan aliran organisisme, masyarakat merupakan kesatuan hidup, dimana individu-individu menempati kedudukan bawahan (subordinate) dan fungsional bagaikan organ-organ badan. Keseluruhan didahulukan atas kepentingan individual, ketunggalan atas kejamakan, keseragaman atas keanekaragaman. Aliran ini biasanya dianut oleh para pemikir yang mengedepankan paham positivisme.

Sedangkan mekanisisme memandang masyarakat sebagai perhimpunan individuindividu yang masing-masing berdiri sendiri dan hanya atas cara lahiriah berinteraksi satu dengan yang lainnya. Apa yang disebut masyarakat tidak lain dari jaringan relasi-relasi yang ditambahkan dari luar kepada individualitas para pelaku, bagaikan serangkaian atom-atom atau penyusun bagian-bagian mekanisme. Kepentingan-kepentingan individual didahulukan atas kepentingan bersama, kejamakan atas ketunggalan, perbedaan atau konflik atas perpaduan atau kesesuaian paham.

\section{Komparasi Pemikiran Para Filsuf}

Jean Jaques Rousseau berpandangan masyarakat sebagai "kontrak sosial yang diadakan antara pihak-pihak otonom". Sedangkan August Comte menguraikan masyarakat harus dilihat sebagai suatu orde, dimana orde adalah keadaan normal masyarakat yang bertumpu pada sifat sosial manusia yang disebut zoon politicon. Selanjutnya Herbert Spencer memandang masyarakat sebagai organisme yang berdiri sendiri dan berevolusi 
sendiri, lepas dari tanggung jawab anggotanya dan di bawah kuasa suatu hukum, paradigma Spencer tersebut lebih mementingkan kuasa individu dalam membentuk masyarakat. Sedangkan Emile Durkheim membagi masyarakat ke dalam dua jenis, yakni masyarakat kuno dan masyarakat modern. Masyarakat kuno dicirikan oleh suatu solidaritas mekanis, sedangkan masyarakat modern dicirikan oleh solidaritas organis.

Semua pemikiran para filsuf tersebut tidak ada mengindikasikan bahwa masyarakat terbentuk atas dasar kekerasan. Konstruksi masyarakat yang di idamkan oleh para filsuf adalah masyarakat damai atas kesepakatan diantara pihak-pihak otonom. Meski perbedaan pandangan pada masyarakat kerap kali terjadi, keadaan normal (orde) itu harus tetap terjaga dan terlaksana. Artinya; susunan masyarakat yang tertib, tidak harus dimaknai sebagai sesuatu yang tidak pernah terjadi perubahan dan perkembangan, masyarakat adalah dinamis.

Konstruksi masyarakat yang damai dan tanpa kekerasan oleh para filsuf disadari menjadi bayangan masyarakat dunia. Terminologi bayangan adalah untuk menunjukkan situasi konkret masyarakat dunia yang sedang dihantui oleh tragedi kemanusiaan berupa munculnya pandemi covid-19, provokasi politik identitas oleh Habib Riziq Sihab di Indonesia, kelompok kekerasan bersenjata $(\mathrm{KKB})$ di Papua, pembataian terhadap ras tertentu di Myanmar, pengambil-alihan kekuasaan oleh militer di Myanmar, serta bentuk-bentuk genocida yang terjadi dibelahan dunia belakangan ini.

Dalam sebuah artikelnya, Paul Ricoeur mengatakan bahwa teks atau wacana adalah "any discourse fixed by writing" (Ed. Thomson, 1982:145; Terj. Syukri, 2006: 196). Dengan istilah "discourse" ini, Ricoeur merujuk kepada bahasa sebagai event, yaitu bahasa yang membicarakan sesuatu, bahasa yang di saat ia digunakan untuk berkomunikasi. Sementara itu, teks merupakan sebuah korpus yang otonum yang dicirikan oleh empat hal berikut ini (Permata dalam Ricoeur, 2003: 217-220):

Pertama, dalam sebuah teks makna yang terdapat pada apa yang dikatakan (whath is said) terlepas dari proses pengungkapannya (the act of saying), sedangkan dalam bahasa lisan kedua proses itu tidak dapat dipisahkan. Kedua, dengan demikian makna sebuah teks juga tidak lagi terikat kepada pembicara, sebagaimana bahasa lisan. Apa yang dimaksud teks tidak lagi terkait dengan apa yang awalnya dimaksudkan oleh penulisnya. Bukan berarti bahwa penulis tidak lagi diperlukan. Akan tetapi, maksud penulis sudah terhalang oleh teks yang sudah membaku. Ketiga, karena tidak terikat pada sebuah sistem dialog, maka sebuah teks tidak lagi terikat kepada konteks semula (ostensive reference). Ia tidak terikat pada konteks asli dari pembicara. Apa yang ditunjuk oleh teks, dengan demikian adalah dunia imajiner yang dibangun oleh teks itu sendiri, dalam dirinya sendiri maupun dalam hubungannya dengan teks-teks yang lain. Keempat, dengan demikian juga tidak lagi terikat kepada audiens awal, sebagaimana bahasa lisan terikat kepada pendengarnya. Sebuah teks ditulis bukan untuk pembaca tertentu, melainkan kepada siapa pun yang bisa membaca dan tidak terbatas pada ruang dan waktu. Sebuah teks membangun hidupnya sendiri karena sebuah teks adalah sebuah monolog.

Dengan demikian interpretasi dalam perspektif Paul Ricoeur adalah karya pemikiran yang terdiri atas penguraian makna tersembunyi (sens cache) dari makna yang terlihat (sens apparent) pada tingkat makna yang tersirat di dalam makna literer. Simbol dan interpretasi menjadi konsep yang saling berkaitan. Interpretasi muncul di saat makna jamak berada dan di dalam interpretasilah pluralitas makna termanifestasikan (Bleicher, 2003: 376).

Selanjutnya Ricoeur menguraikan, interpretasi dilakukan dengan perjuangan melawan distansi kultural, yaitu penafsiran harus mengambil jarak agar dia dapat melakukan interpretasi dengan baik. Namun, yang dimaksud Paul Ricoeur dengan "distansi kultural" itu tidaklah steril dari "anggapan-anggapan". Selain itu, yang dimaksud dengan "mengambil jarak terhadap peristiwa sejarah dan budaya" tidak berarti seseorang bekerja dengan "tangan kosong" (Sumaryono, 1999: 106). Posisi pembaca bekerja tidak dengan "tangan kosong" ini 
seperti halnya posisi karya sastra itu sendiri yang tidak diciptakan dalam keadaan kekosongan budaya (Teeuw, 1980: 11). Akan tetapi, seorang pembaca atau penafsir itu masih membawa sesuatu yang oleh Martin Heidegger disebut vorhabe (apa yang dia miliki), vorsicht (apa yang dia lihat), dan vorgriff (apa yang akan menjadi konsepnya kemudian). Artinya, seseorang dalam interpretasi tidaklah dapat menghindarkan diri begitu saja dari prasangka (Sumaryono, 1999: 107).

Menurut Johan Galtung (dalam Windu, 1999: 1) dunia ini sedang dilanda banyak krisis. Galtung menyebutkan terdapat 4 macam krisis yang melanda dunia, yaitu; krisis kekerasan, krisis penderitaan, ancaman represi, dan krisis lingkungan hidup. Sementara Gandhi (1981: 45-46) pernah menyebut betapa masyarakat atau manusia terlalu mudah menggunakan kekerasan sebagai alat untuk menyelesaikan setiap persoalan kemanusiaan yang dihadapinya, meski itu merupakan persoalan yang sepele dan remeh.

Realitas kekerasan dalam sistem sosial kemudian menimbulkan dua anggapan, yakni; Pertama, sebagaimana di uraikan Thomas Hobbes dalam tesisnya Leviathan (Suseno, 1987: 200-207) yang beranggapan bahwa kekerasan merupakan naluri dasar manusia yang selalu dikuasai oleh dorongan-dorongan irasional dan anarkis. Sosok manusia yang demikian disebut sebagai Homo Homini Lupus, manusia adalah serigala bagi manusia yang lain dan akibatnya perang semua lawan semua (bellum omnium contra omnes) kerap kali terjadi. Kedua, sebagaimana dikemukakan oleh Jean Jacques Rousseau (1712-1778) justru menganggap bahwa manusia keadaan alamiahnya sebagai ciptaan yang polos, mencintai diri secara spontan, tidak egois dan tidak altruis (Lubis, Peny., 1988: 43). Hanya rantai peradabanlah yang telah membentuk manusia menjadi binatang yang memiliki sifat menyerang seperti keadaannya saat ini.

Perilaku kekerasan yang dilakukan manusia dalam sebuah sistem sosial dengan demikian dapat saja berawal dari sifat dasar manusia, sebagaimana anggapan Thomas Hobbes, atau juga karena sistem sosial yang melingkupinya yang mendorong munculnya perilaku kekerasan dalam masyarakat. Dua pendekatan penyebab kekerasan ini, bukan hendak menjadi titik tolak pembahasan, melainkan untuk menunjukkan suatu fakta secara teoretis bahwa peradaban umat manusia selalu dihantui oleh munculnya fenomena kekerasan.

Fenomena yang demikian seolah menjadi legitimasi bagi munculnya kekacauan (chaos) dalam masyarakat sebagai sesuatu yang wajar terjadi, apalagi masyarakat yang tengah menghadapi problem perubahan. Persoalannya apakah perilaku kekerasan dalam masyarakat harus juga dihadapkan dengan kekerasan. Jika demikian, maka penyelesaian kekerasan dalam masyarakat dengan kekerasan sesungguhnya hanya memunculkan suatu model atau tipe masyarakat yang secara substantif mempunyai sifat dasar kekerasan.

Masyarakat yang mengedepankan kekerasan dalam menyelesaikan masalahnya, tidak akan pernah dapat menghapuskan kekerasan secara tuntas. Justru memberi peluang munculnya problem kekerasan baru, karena masih ada sisa dalam penyelesaian kekerasan. Dalam konteks ini, pemikiran Gandhi (1981: 8-15) tentang perlawanan tanpa kekerasan menjadi menemukan relevansinya. Masyarakat yang dibiasakan melawan kekerasan tidak dengan kekerasan pada akhirnya dapat berpeluang menciptakan tatanan masyarakat yang damai dan tanpa konflik.

\section{SIMPULAN}

Paradigma para filsuf tentang konsep masyarakat pada dasarnya mengarah kepada terwujudnya kesatuan yang dinamis, yakni suatu susunan masyarakat yang tetap dan tertib, damai, sejahtera atas dasar kesepakatan diantara pihak-pihak otonum. Meski diantara mereka terdapat perbedaan pandangan tentang konsep masyarakat akan tetapi semuanya tidak mengharapkan/ menginginkan terjadinya kekacauan (chaos) dan perilaku anarkis 
dalam masyarakat.

\section{DAFTAR PUSTAKA}

Bleicher, Josef (2003). Hermeneutika Kontemporer. Terj. Ahmad Norma Permata. Yogyakarta: Fajar Pustaka.

Galtung, Johan (2002). Kekerasan Kultural, dalam Jurnal Wacana, edisi 9 Tahun III, 2002. Yogyakarta: INSisT.

Gandhi, M.K. (1981). Ashram Observance in Action, terj. Gedong Bagoes Oka. Bali: Yayasan Bali Santi Sena.

Gandhi, M.K. (1950). Religi Susila, terj. Sumirat. Jakarta: Balai Pustaka.

Gandhi, M.K. (1988). Semua Manusia Bersaudara, Kehidupan dan Gagasan Mahatma Gandhi Sebagaimana Diceritakan Sendiri. Terj. Kustiniyati Mochtar, kata pngantar Mchtar Lubis. Jakarta: Obor dan Gramedia.

Hadi W.M., Abdul (2014). Hermeneutika Sastra Barat \& Timur. Jakarta: Sadra Press.

Iver, Mac and Charles H. Page (1961). Society, an introductory analysis. London: Macmillan \& Co. Ltd.

Lubis, Mochtar, (1988). Menggapai Dunia Damai. Jakarta: Yayasan Obor Indonesia.

Mutakin, Awan, (1998). Studi Masyarakat Indonesia. Jakarta: Depdiknas Dirjen Dikdasmen.

Palmer, Richard E. (2003). Hermeneutika, Teori Baru Mengenai Interpretasi. Terj. Musnur Hery. Yogyakarta: Pustaka Pelajar.

Purwadarminta, WJS, (1982). Kamus Besar Bahasa Indonesia. Jakarta: Balai Pustaka.

Ricoeur, Paul (2003). Filsafat Wacana, Membelah Makna dalam Anatomi Bahasa. Terj. Musnur Hery. Yogyakarta: Ircisod.

Ricoeur, Paul (1976). The Interpretation Theory: Discourse and The Surplus Meaning. Forthworth, Texas: The Texas Christian University Press.

Ricoeur, Paul (1978). The Rule of Metaphore: Multi-Disciplinary Studies of the Creation of Meaning in Language. Tranlated by Robert Czermy. London: Routledge \& Kegan Paul Ltd.

Ricoeur, Paul (1982). Hermeneutics and The Human Science: Essays on Language, Action, and Interpretation. Editor John B. Thompson. Cambridge: Cambridge University Press.

Ricoeur, Paul (2006). Hermeneutika Ilmu Sosial. Terj. Muhammad Syukri. Yogyakarta: Kreasi Wacana.

Soekanto, Soerjono, (1999). Sosiologi, Suatu Pengantar. Jakata: Rajawali Press.

Soelaiman, Munandar, (1993). Ilmu Sosial Dasar. Bandung: PT. Eresco.

Sumaryono, E. (1999). Hermeneutika: Sebuah Metode Filsafat. Yogyakarta: Kanisius.

Suseno, Frans Magnis, (1988). Etika Politik. Jakarta: Gramedia.

Suseno, Frans Magnis, (1987). Kuasa dan Moral. Jakarta: Gramedia.

Teeuw, A. 1983. Tergantung pada Kata. Jakarta: Pustaka Jaya.

Veeger, K.J., (1993). Realitas Sosial, Refleksi Filsafat Sosial atas Hubungan IndividuMasyarakat Dalam Cakrawala Sejarah Sosiologi. Jakarta: Gramedia Pustaka Utama.

Windhu, I. Marsana, (1999). Kekuasaan dan Kekerasan Menurut Johan Galtung. Yogyakarta: Kanisius. 